\title{
Bioengineering of Neem Colloidal Nano-Emulsion Formulation With Adjuvant for Better Surface Adhesion and Long Term Activity in Insect Control
}

\section{Research Article}

Keywords:

Posted Date: July 7th, 2021

DOI: https://doi.org/10.21203/rs.3.rs-116370/v2

License: (c) (1) This work is licensed under a Creative Commons Attribution 4.0 International License.

Read Full License 


\section{Abstract}

The authors have requested that this preprint be withdrawn due to a need to make corrections.

\section{Full Text}

The authors have withdrawn this preprint from Research Square. 